\title{
CONTEMPORARY POSSIBILITIES OF TREATING VASOFORMATIVE TISSUE TUMOURS
}

\author{
Eva Justováa ${ }^{\text {, Jindřich Pazderaa }}$, Vladimír Mihál ${ }^{b}$ \\ a Clinic of Oral and Maxillofacial Surgery, Faculty of Medicine, Palacky University, Olomouc, Czech Republic \\ b Pediatric Clinic, Faculty of Medicine, Palacký University, Olomouc, Czech Republic
}

Received July 20, 2000

Key words: Vasoformative tissue tumours / Haemangiomas / Therapy

The authors present a review of up-to-date methods of vasoformative tissue tumours treatment. The necessity to choose the best therapy and the risks of single therapeutical procedures are pointed out.

Vasoformative tissue tumours, haemangiomas especially, are the most common benign tumours. Their development, diagnostics and therapy has so often been discussed in professional literature that the whole problematic should seem to be definitely solved. Clinical practice, however, disproves these opinions, as contemporary clinical investigations and introduction of new therapeutic procedures have confirmed.

In many cases haemangiomas are diagnosed in childhood. We can find them in 10-12\% normaly delivered and as much as $22 \%$ preliminary delivered children with a delivery weight less than $1000 \mathrm{~g}$. The tumours occur three times more often in girls ${ }^{64}$.

Histologically, these tumors are either hamartomas, or true tumours. They are characterized by quick proliferation in the period between 8 and 18 months after delivery. The proliferation can during the following 5-8 years be changed by slow regression (phase of involution). Total tumour regression is possible in $50-70 \%$ of cases. Exceptions are tumours located in orofacial region. Many physicians still underestimate the importance of this disease. Patient can be seriously damaged by neglect or by missing the period, suitable for the treatment of proliferating haemangiomas. Multilocular haemangiomas of the skin (diffusal haemangiomatosis) and large haemangiomas of the face are often accomanied by visceral haemangiomas (Parkinson-Weber Syndrome). This is the reason why sucklings suffering multilocular haemangiomas of the skin should undergo screening of abdominal cavity by means of sonography or dopplerometry ${ }^{98}$. Large haemangiomas of the neck and face can be connected with multiple anomalies, known as PHACES Syndrome (malformation of the posterior cranial fossa, haemangiomas of cervicofacial region, arterial malformations, anomalies of the heart, eyeballs, thoracic and abdominal clefts, etc. $)^{79}$. Other syndromes, connected with haemangiomas, are e.g. Sturge-Weber Syndrome, Gorau Syndrome, KlippelTrenaunay Syndrome, etc. Central maxillary haemangioma combined with retinal angiomatosis is known as
Von Hippel Disease. Other important syndromes are the Louis-Bar Syndrome (ataxia and teleangiectasia) and the Kasabach-Meritt Syndrome (thrombocytopenia with coagulopathy). Venous and arteriovenous mal-

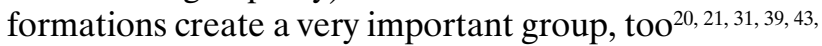
$73,76,92$.

Tumours can be classified both from the point of view of histopathological structure and/or clinical picture. According to histopathological structure we can diferentiate between capillary and cavernous haemangiomas. Clinical classification of these tumours consists of four groups: naevus flammeus, haemangioma simplex, haemangioma cavernosum and haemangioma faciei $^{96}$.

In childhood, haemangiomas have various clinical pictures. Capillary "strawberry" haemangioma mainly localized on the head and neck can be diagnosed mostly in neonatal period. Cavernous haemangiomas can appear either in neonatal period or during the first six months in any area of the human body (liver, pericardium, orbit, subglottic area etc. $)^{63,81,84}$. "Alarming" haemangiomas (Enjolras et al.) are called the tumors which damage important "vital" structures and endanger the child s life by serious complications $\mathrm{s}^{32,33,79}$.

Large tumours or vascular malformations of the face can be very difficult to treat. New ways of treatment must be looked for because the mortality of these diseases varies between 40-60\% $\%^{3,56,57}$. A tumour, which in its substance is benign, can endanger the patient's life by its malignant localization (orbit, liver, etc.) The logical consequence is a highly varied spectrum of treatment methods. Beside „classical“ therapies (surgery, embolization of tumor caverns, sclerotherapy, cryotherapy, use of corticosteroids) other new up to date methods have appeare $\mathrm{d}^{99}$. In some patients contemporary treatment methods fail because of the tumour's size, localization or resistance to treatment. In fact, the rule "primum non nocere" must be respected especially in children, where a mutilating surgical procedure in the face sometimes combined with massive bleeding could represent 
an unacceptable risk both for the surgeon and the small patient. There are similar situation's in the case of large, particularly cavernous haemangiomas with the above mentioned "malignant" localization in adults. The treatment strategy must be strictly individual. It is necessary to use combined methods so as to get optimal treatment results and minimize complications and disadvantages of the single ways of treatment ${ }^{2}$. In spite of these possibilities and progress in modern health care there are some problems hard to solve at the contemporary level of knowledge. We are sure that it is just here where new space opens for new, up-to-date therapeutic procedures as e.g. treatment of areal haemangiomas (naevus flammeus) by means of a colour laser, systemic therapy of „alarming“ haemangiomas by means of Interferon alfa $2 \mathrm{a}$ or embolization of tumours after preliminary superselective arteriography.

There are many less or more invasive methods in conservative treatment of haemangiomas which are mentioned in the following table:

A review of therapeutic procedures in the treatment of haemangiomas

- Local ways of treatment:

Laser therapy

Radiotherapy

Electrocoagulation

Sclerotization (Aethoxysclerol)

Cryosurgery

Therapeutic embolization

Surgery

- Systemic ways of treatment:

Corticoid administration

Systemic application of interferons

Under the level of contemporary experience, surgery still holds a dominant position on the scale of therapeutic possibilities. Surgical treatment is the procedure of choice regarding to the type, location and size of the tumour. Large haemangiomas are often a great therapeutic problem because of the high risk of periand postoperative bleeding. Surgical procedure consists in tumour extirpation (often after sclerotization, embolization or external carotid artery ligature). Large haemangiomas of the orbit can be, in extreme cases, removed only using radical exenteration of the orbital tissues. Surgical treatment of a large haemangioma of the face must be followed both by reconstruction and rehabilitation. A surgery brings about many risks. In many cases, it has to be completed or replaced by other therapeutic procedures. We use it for all small and medium sized cavernous and capillary haemangiomas up to the size of a hazelnut. The exstirpation is usually a single, only larger tumours require gradula intervention $^{56}$.

The next invasive method of treating haemangiomas is embolization. It has two aims: when the emboli penetrate the tumour tissue with large enough stalks, it has a therapeutic effect and reduces or stabilizes of the size of the cavernoma, making the later classical surgery easier ${ }^{62,80,105}$. When the embolizing particles only obturate the arterial stalk of the haemangioma, embolization has a hemostatic effect and it is performed as a preparation for an operation with an imminent blood loss. The preparations currently used are Gellaspon, Bucrylat or Histoacryl. Another possibility are silicon balls with baryum. To prove arteriovenous short circuits in orofacial area phlebography, arteriography or selective arteriography and dopplometric examination are used ${ }^{69,73}$. Artificial embolization in the area of the external carotid must be preceeded by carotid angiography ${ }^{19,20,21,22}$. A surgeon should be present during the examination, who assisted by a radiologist, will decide about further therapy. Large tumours, which are difficult to remove surgically, can be treated by embolization. Its extent is determined by the character of the vascular supply of the tumour - i.e. by the site and size of the supplying blood vessels. This method is used first of all for terating hemangiomas diffusely infiltrating into the soft tissues of the face and neck ${ }^{59}$.

Cryalization is based on tissue destruction by necrotizing temperatures $\left(-20{ }^{\circ} \mathrm{C}--196^{\circ} \mathrm{C}\right)$ causing irreversible necrosis followed by elimination of the necrotic tissue. The cryocycle must usually be repeated. The depth of necrotization is up to $10 \mathrm{~mm}$. The best freezing time is $30-40$ seconds at $-186{ }^{\circ} \mathrm{C}$.

Although cryodestruction is quite an old method ${ }^{83}$, it still has its justified use ${ }^{10,30,37,41,61,75,91}$. In this country, those who have got large practical experience with cryotherapy are especially Průcha, Kostřica, Žaloudík and Šbestová $^{82,90}$. We recommend this method particularly for cavernous haemangiomas of the tongue, where we have had almost a hundred per cent success ${ }^{53,89}$. The method is suitable for high risk patients, for elderly patients, and in cases where for some reason, no other method can be used. In orofacial area it brings about not only a therapeutic but also aesthetic success, except for skin hemangiomas, where it can leave aesthetically disturbing scars ${ }^{66}$.

One of the least invasive methods of treating tumours is using a laser ray ${ }^{5,8}$. Laser therapy is a relatively new method. It is based on maximum absorption of laser energy by target chromophors with a minimum thermal damage to the surrounding tissues. This phenomenon is explained in the theory of selective photothermolysis (Anderson, Parish). According to the type of the medium used we can divide lasers into several groups:

1. Gas - argon, $\mathrm{CO}_{2}$, He-Ne laser

2. Solid - Nd: YAG laser, semiconductor lasers

3. Liquid - dye laser (laseractive atoms are dissolved in a liquid)

The most common surgical laser is the $\mathrm{CO}_{2} \operatorname{laser}^{17,100}$. It is used for parenchymatous organs, because it coagulates blood vessels. The flashlamp pumped dye laser has recently been recommended for vasoformative tissue tumours 4 , 9, 24, 28, 35, 36, 60. We have used the Chromos 585 dye laser Sharplan (wave lenght $585 \mathrm{~nm}$, energy density $2.5-10 \mathrm{~J} / \mathrm{cm}^{2}$ ). We regard the dye laser as suitable for all 
types of angiomatous naevi, hemangiomas (especially skin forms), naevus flammeus in the face and on the neck, including the Sturge-Weber Syndrome and teleangiectasis.

Non-invasive methods of treating vasoformative tissue tumors are radiotherapy, sclerotization and systemic cures with corticoids or interferons ${ }^{13}$. Apart from surgery, radiation therapy in orofacial region occupies an important place, though only in strictly defined indications. The kind of treatment, irradiation source and especially the dose and fractionation of the irradiation as well as the time of irradiation and the extent of the irradiated tissue are usually decided upon by an oncologist and radiotherapeutist. The aim of radiotherapy is elimination of the tumour tissue without early or late damage to surrounding healthy tissues. For the oral cavity and face, this method is only used in case of a total failure of other methods available for the proliferatively growing large haemangiomatoses of the head and neck. Endotelial cells of the haemangiomas are of embryonal nature and they are very sensitive to radiation. During maturation their sensitivity decreases. Therefore the aim of irradiation is not their fast destruction, but an induction or acceleration of their involution. Controversial opinions on children's hemangioma treatment were pointed out by Bek and Koutecký, who themselves recommend radiation therapy in indicated cases $^{14,15,16}$. For capillary "strawberry" haemangiomas, which occur mostly in the area of the head and neck and initially grow very fast, low dose therapy is recommended only in complicated cases (amblyopia).

One of the conservative methods of treating vasoformative tissue tumours is sclerotization. This method consists in intratumorous application of sclerotizing preparations ${ }^{47}$, which irritate the intima and cause reactive thrombophlebitis with tissue proliferation and scarring ${ }^{51}$. The best of all agents available is Aethoxysklerol-Kreussler in $0.5-3 \%$ concentration - which we have been using for twenty years ${ }^{49}$. No side effects have been registered except for local swellings due to histamine-type activity. That can be blocked with a suitable antihistaminic ${ }^{50}$. Sclerotherapy has been worked out in detail at our Department. We sclerotize vasoformative tissue tumours wherever surgical intervention is not suitable because of the size or the location of the tumour, e.g. in large cavernous haemangiomas of the tongue, tumours in the mouth corner, or hemangiomas of the pharyngeal wall. The next indication is demarcation of the tumour before the operation in order to reduce its size, to decrease operation bleeding and to cure the residua left after tumour exstirpation. We use sclerotization to treat circumscribed recurrences of vascular angiomas. In some cases, sclerotization is a method of choice, especially in aesthetically important parts of the face, in others it is an alternative method ${ }^{44,48}$.

Systemic corticoid therapy has become dominant in haemangioma treatment in children, though its effect upon the tumour tissue has not been cleared $u^{38}$. Recommended doses are $2-3 \mathrm{mg} / \mathrm{kg}$ (sometimes up to 5 $\mathrm{mg} / \mathrm{kg}$ ) a day. In one third of the patients this treatment leads to a dramatic reduction of the haemangioma within a few days, in about one third of the sucklings the tumour stops growing and in the remaining children the response is very poor or none. In spite of undesired side effects most children take this treatment well and their retarded growth is corrected after the end of the therapy. Large doses of intravenous methylprednisolon have been used for life-threatening and "alarming" haemangiomas and in cases of the Kasabach-Meritt phenomenon. To small, localized skin haemangiomas corticosteroids can be applied directly into lesions. The amount of triamcinolon should not exceed 3-5 mg for one dose. But this treatment is counterindicated with haemangiomas of periorbital area (skin atrophy, necrosis and occlusion of the retina artery with following blindness ${ }^{93}$ ). Another recommended indication are vasoformative tissue tumours situated in the parotis and parenchymatous organs. We were forced to use systemic and intratumorous corticoid therapy (local application of Urbason, systemic use of Triamcinolon) for a six-month-old child with large hemangiomatosis in the face, oral cavity and neck. Because the tumour proliferated into the nasopharynx we had to combine the treatment with actinotherapy.

Interferons (IFN) have recently been advocated for their antiangiogenic effect in systemic therapy of haemangiomas, above all for "alarming" and life-threatening tumours ${ }^{7,26,29,79,101,102,103,104}$. Although we still do not know exactly the mechanism which controls the growth and regression of hemangiomas, the latest knowledge of angiogenesis and blood vessels evolution helps to understand it better. Vasculogenesis relates to the processes in which new vessel develop from the precursors of endothelial cells, whereas during angiogenesis the already existing vessels mature.

The antiangiogenic effect of interferon was described as early as 1970 by Folkman. IFN inhibits angiogenic molecules of the tumour cells ${ }^{11,34}$. Inhibitors are able to penetrate into the finest capillaries of the blood system $^{78}$. The ability of IFN to potentiate tumoricide activity of some cytostatics has its share in the anti-tumour effect $^{72}$. A promising factor is the strong synergism between alpha IFN and platinum derivates, but also between IFN and retinic acid derivates which were proved to increase S-tat 1 expression. We succeeded in verifying the effect of alpha 2 a interferon upon the vasoformative tissue tumours, inoperable because of their size or location (orbit), when preparing patients for a surgery (reduction of bleeding), or in cases when the recommended therapy had failed ${ }^{58}$. New knowledge of the transmission of the activating signal of the IFN led to a change in the dosage. One million units was found to be enough as a maintenence daily dose. New dosing can in these cases reduce the undesired effect ("flu syndrome", neutropenia, liver enzyme abnormalities and, for children, neurological complications). This type of therapy can be performed only where its success can be assessed from some specific cellular signs of angiogenesis (e.g. urine based fibroblastic growth factor). Such findings 
could help to determine the optimal doses of the medicine. No interferon therapy can be started without the agreement of both experts (pediatrist, dermatologist, maxillofacial surgeon, oncologist) and the child's parents.

Despite many therapeutic alternatives, the treatment of vasoformative tissue tumours brings about a lot of risk and problems. Therefore the indication and the type of therapy must be a result of team cooperation.

\section{REFERENCES}

1. Adzick, N. S., Strome, M. (1984) Cryotherapy of subglotic hemangioma. J. Pediatr. Surg., 19, 353-357.

2. Airoldi, M., Fazio, M. (1985) Combined cryosurgical, chemotherapeutic, and radiotherapeutic management of T 1-4 NOMO oral cavity cancers. Cancer, 56, 424-431.

3. Alan, R., Ezekowitz, B. (1992) Interferon alfa2a. Therapy for life - threatening Hemangiomas of Infancy. The New England Journal of Medicine, 1456-1463.

4. Alster, T. S., Me Meekin, T. O. (1996) Improvement of facial acne scars by the $585 \mathrm{~nm}$ flushlamp-pumped pulsed dye laser. Journal of the American Academy of Dermatology, 35, 1, 79-81.

5. Amir, N. (1993) Alexandrite Laser Offers Tatoo Removal without Scarring or Skin Texture Changes. Journal of Clinical Laser Medicine \& Surgery, 11, 5, 263-266.

6. Andrés, M. (1991) Klinické využití metody spray freezing v oftalmologii. Československá oftalmologie, 47, 3, 198-204.

7. Appelbaum, F. (1990) Introduction and overview of interferon alpha in myeloproliferative and hemangiomatous diseases. Seminars Hematol., 27, 4, 1-5.

8. Appelberg, D. B., Maser, M. R., Lash, H. (1981) The argon laser for cutaneous lesions. J.A.N.A., 245, 2037-2075.

9. Ashinoff, R., Geronemus, R. G. (1993) Failure of the FlashlampPumped Pulsed Dye Laser to Prevent Progression to Deep Hemangioma. Pediat. Derm., 10, 1, 77-80.

10. Autery, F., Alessandro, L. (1993) Cryotherapy as an alternative intervention to surgical excision in the management of cancer of the rectum. Clin. Ter., 142, 347-350.

11. Barlow, C. F., Priebe, C. J., Mulliken, J. B. (1998) Spastic diplegia as a complication of interferon Alfa-2a treatment of hemangiomas of infancy. Journal of Pediatrics, 132/31, 527-530.

12. Bauman, R. (1991) Combined treatment with HIV related Kaposis sarkoma. Klin. Wochenschrift, 69,8 , 813-816.

13. Baumarsh, H., De Chiara, S. (1991) A conservative approach to the management of orofacial vascular lesions in infants and children: report of cases. J. Oral. Maxillofac. Surg., 49, 11, 1222-1225.

14. Bek, V. (1966) Angiomy dětského věku. SzdN, Praha.

15. Bek, V., Koutecký, J. (1980) Dětské hemangiomy jako stále aktuální problém. Čs. Pediat., 35, 2, 76-80.

16. Bek, V., Koutecký, J., Abrahámová, J. (1980) Některé nové poznatky a aspekty v klinice hemangiomů a stanovisko k problému léčit či neléčit? Čs. Pediat., 35, 2, 76-80.

17. Bellina, J. H., Heminings, R., Voros, J. (1983) Carbon dioxide laser and electrosurgical wouded study in animal model. Lasers in surgery and medicine, 3, 2, 144.

18. Bláhová, K., Mottl, M., Tůma, S. (1991) Hemangiomatóza jater u tříměsíčního kojence. Čs. Pediat., 46, 8-9.

19. Bohutová, J. (1983) Intraarteriální arteficiální embolizace u vaskularizovaných nádorů v povodí zevní krkavice. Čs. Radiol., 37, 2, 57-69.

20. Bohutová, J. (1998) Endovasculární léčba patologických procesů v oblasti hlavy a krku zásobených $\mathrm{z}$ arteria carotis externa. Čs. Radiol., 52, 78-82.

21. Bohutová, J., Toman, J. (1980) Selektivní intraarteriální a arteficiální embolizace v maxilofaciální oblasti. Čas. Lék. čes., 119, 7 , 193-224.

22. Bohutová, J., Kolář, J., Olejníček, H. (1981) Treatment of heavy epistaxis by intraarterial embolization. Radioterapie, 21, 2, 81-83.
23. Bohutová, J., Koláŕ, J., Mazánek, J. (1991) Zkušenosti s využitím některých druhů embolů v povodí arteria carotis externa. Čs. Radiol., 45, 3, 129-138.

24. Brandt, F., Bellman, B. (1996) Pulsed Dye Vascular Laser for the Treatment of Striae Distensiae. Clinical Update, 1, 2.

25. Buchner, S. A. (1993) Kryochirurgie bei malignen Tumoren des Haut. Ther. Umsch. Dec. 50, 848-851.

26. Catanil, L. (1992) In vitro inhibition of interferon alfa2 antiproliferative acitivity by antibodies developed during treatment for essential trombocythemia. Haematologia, 77, 318-321.

27. Crewford, G. M. (1984) Injection therapy for angiomas. J. Amer. dent. Ass., 137, 519-527.

28. Daniel, D. H., Ash, K., Zukowski, H. (1992) Repair of Stretch Marks with the $585 \mathrm{~nm}$ Pulsed Dye Laser: An Overview and Clinical Experience. Bedford.

29. Deb, G., De Stefano, F., De Sio L. (1998) Interferon alfa 2a in the treatment of serious hemangiomas of infants. $10^{\text {th }} \mathrm{NCI}-$ EORTC symposium on new drugs in cancer therapy. Amsterdam, June 16-19. Abstract books, 177.

30. De Coster, D., Bossuyt, M., Fossion, E. (1993) The value of cryotherapy in the management of trigeminal neuralgia. Acta Stomatol. Belg., 90, 87-93.

31. Dobbelaere, P., Pellerin, P., Donazzan, M., Clarisse, J. (1984) Indicitations des embolisations selectives en pathologie maxillofaciale. Rev. Stomatol. Chir. Maxillofac., 85, 3-11.

32. Drolet, B. A., Esterly, N. B., Merland, J. J., Escaude, J. P. (1990) Management of alarming hemangiomas of infancy: a review of 25 cases. Pediatrics, 85, 491-498.

33. Enjoras, O., Riche, M. C., Merland, J. J., Escaude, J. P. (1990) Management of alarming hemangiomas of infancy: a review of 25 cases. Pediatrics, 85, 491-498.

34. Feldman, D., Goldstein, A. L., Cox, D. C., Grimley, P. M. (1988) Cultured human endotelial cells treatment with recombinant leukocyte A interferon: tubuloreticular inclusion formation, antiproliferative effect, and 2,5 oligoadenylate synthetase induction. Lab. Invest.

35. Garden, J. M., Bakus, A. D. (1993) Clinical Efficacy of the Pulsed Dye Laser in the Treatment of Vascular Lesions. J. Dermatol. Surg. Oncol., 19, 321-326.

36. Geronemus, R. G. (1993) Pulsed Dye Laser Treatment of Vascular Lesions in Children. J. Dermatol. Surg. Oncol., 19, 303-310.

37. Gongloff, R. (1983) Treatment of intraoral hemangiomas with nitrous oxide cryosurgery. Oral Surg. Oral Med. Oral Pahtol., 56, 20-24.

38. Gozal, D. (1990) Diffuse neonatal haemangiomatosis: successfull management with high dose corticosteroides. Eur. J. Pediatr., 5, 321-324.

39. Glowacki, J., Mulliken, J. B. (1982) Mast cells in hemangiomas and vascular malformation. Pediatr., 70, 48-72.

40. Huston, J., Forbes, G. S., Reufenacht, D. A., Jack, C. R. et al. (1992) Magnetic resonance imaging of facial vascular anomalies. Mayo Clin. Proc., 67, 739-747.

41. Hutowska, M., Chibowski, D. (1979) Kriochirurgia v leczeniu mnogich naczniakow jazyka. Czas. stomat. 32, 12, 1177-1182.

42. Iwasak, T., Hayshi, Y. (1990) Interferon-treatment for cervical intraepithelial neoplasia. Gynecol. Oncol., 37, 96-102.

43. Jackson, T., Carreno, R., Potparic, Z., Hussain, K. (1993) Hemangiomas, vascular malformations, and lymfovenous malformations: classification and methods of treatment. Plast. Reconstr. Surg., 7, 1216-1230.

44. Justová, E. (1986) Skleroterapie hemangiomů v orofaciální oblasti a experimentální ověření jejího účinku. Kandidátská disertační práce, Olomouc.

45. Justová, E. (1988) Současná problematika vzniku, utváření, diagnostiky a léčby hemangiomů. I. Čs. stomat., $88,4,311-313$.

46. Justová, E. (1988) Současná problematika léčby hemangiomů. II. Čs. stomat., 88, 5, 371-373.

47. Justová, E. (1990) Léčení hemangiomů orofaciálního systému sklerotizací. Ćs. Stomat., 90, 6, 436-445.

48. Justová, E., Jirava, E. (1982) Sklerotizace hemangiomů v orofaciální oblasti. Čs. stomat., 82, 2, 122-127.

49. Justová, E., Lenfeld, J., Mand’áková, M. (1985) Experimentální zhodnocení dráždivosti př́ípravku Aethoxysklerol. Čs. Stomat., $85,6,390-396$. 
50. Justová, E., Lenfeld, J., Mand’áková M. (1986) Mechanismy počátečního dráždivého účinku Aethoxysklerolu. Čs. Stomat. $86,2,136-142$.

51. Justová, E., Lenfeld, J., Dušek, J. (1991) Časné a pozdní změny po aplikaci preparátu Aethoxysklerol-Kreussler. Cs. Stomat., 2, 73-79.

52. Justová, E., Pazdera, J. (1981) Hemangiopericytom dutiny ústní. Cs. stomat., 81, 3, 184-187.

53. Justová, E., Pazdera, J. (1997) Využití kryalizace v léčení nádorů z vazoformativní tkáné. Cs. stomat. 45, 4, 176-182.

54. Justová, E., Pazdera, J. (1997) Léčení nádorů z vazoformativní tkáně. I. Cs. Stomat., 45, 5, 227-229.

55. Justová, E., Pazdera, J. (1997) Léčení nádorů z vazoformativn tkáně. II. Čs. Stomat., 97, 6, 269-272.

56. Justová, E., Pazdera, J. (1999) Léčení nádorů z vazoformativní tkáně. III. Cs. stomat., 99, 1, 37-40.

57. Justová, E., Pazdera, J. (1999) Léčení nádorů z vazoformativní tkáně. IV. Čs. Stomat., 99, 2, 77-81.

58. Justová, E., Pazdera, J., Mihál, V. (1998) Systémová terapie Interferonem alfa $2 \mathrm{a}$ u nemocných s nádory z vazoformativní tkáně a infantilní fibromatózy. Cesko-slovenská pediatrie, 53, 28.

59. Justová, E., Bohutová, J., Mazánek, J., Pazdera, J. (1999) Terapeutická úskalí nádorů z vazoformativní tkáně. Choroby hlavy a krku (Head and Neck Diseases), 2, 31-38.

60. Justová, E., Pazdera, J., Zajíc, P., Vantuchová, Y. (2000) Pulsní barvivový laser v léčení nádorů z vazoformativní tkáně. Čs. Stomat. in press.

61. Kalteich, W. E., Filary, G. (1981) Temperaturmesingen bei der Kryoterapie von kavernosen Hämangiomen. Kinderärztl. Prax., 49, 10, 527-534.

62. Kendal, B., Mosley, I. (1977) Therapeutic embolization of the external carotid arterial tree. J. Neurol. Neurosurg., 40, 10, 837-950.

63. Kirschner, S. G., Heller, R. M., Kasselberg, A. G. (1981) Infantile hepatic hemangioendotelioma with subsequent malignant degeneration. Pediatr. Radiol., 11, 42-45.

64. Koutecký, J. (1978) Nádory dětského věku. Avicenum, Praha.

65. Kronberger, D. (1973) Ergebnisse der Injektions Behandlung Frukindlicher Hamangiome im Gesichtsbereich. Pädiatr. Prax., $13,1,127-132$.

66. Kubisová, J., Satko, I. (1994) Príspevok k terapii tumorov kože kryodeštrukciou. Čs. Stomat., 94, 3-5.

67. Lasc, G. P., Glassberg, E. (1995) $585 \mathrm{~nm}$ Pulsed Dye Laser for the Treatment of Cutaneous Lesions. Clinics in Dermatology, 13, 63-67.

68. Leclerc, J. M., Hamel P. (1996) Treatment of benings vascular neoplasms with recombinant Interferon Alfa A-2B. Canada Montreal.

69. Leikensohn, J. R., Epstein, L., Vasconer, L. O. (1981) Superselective embolization and surgery of noninvoluting hemangiomas and A-V malformations. Plast. Reconstr. Surg., 68, 143-152.

70. Margileth, A. M. (1971) Developmental vascular abnormalities. Pediat. clin. N. Amer., 18, 3, 773-800.

71. Mascarenhas, F., Gaspar, L. (1989) Effectiveness of radiotherapy in non-resectable cavernous hemangioma of line. Acta Med. Port., 2, 3, 147-153.

72. Matsumoto, G., Sasakura, Y. (1996) Local Administration of Recombinant Interleukin-2 and Interferon-B in Oral Squamous Cell Carcinoma. Bulletin of Kanagawa Dental College, 24, 2, 57-63.

73. Merland, J. J., Ricke, M. C., Hadjean, E. (1983) The use of superselective arteriography, embolization, and surgery in the current management of cervicocephalic vascular malformations (350 cases). In: Williams H.B. (Ed.), Symposium on Vascular Malformations and Melanotic Lesions. C. V. Mosby, St. Louis, 135-143.

74. Mlčochová, E. (1962) Subglotický hemangiom jako neobvyklá př́ćčina stridoru u kojenců. Čs. Pediat., 17, 34-37.

75. Mohanty, K. C. (1990) Cryotherapy in the management of histologically diagnosed subclinical human papiloma virus (HPV) infection of the cervix. Br. J. Clin. Pract., 44, 574-577.

76. Mulliken, J. B., Glowacki, J. (1982) Haemangiomas and vascular malformations in infants and children: a classification based on edothelial characteristics. Plast. Reconstr. Surg., 59, 412-422.
77. NCCN Sarcoma Practice Guidelines. NCCN Proceedings. Oncology, 1999, 3, 183-218.

78. Orchard, P. J. (1989) Treatment of haemangioendotheliomas with alpha interferon. Lancet, 2, 665-667.

79. Pascual-Castroviejo, I., Viano, J., Moreno, F. (1996) Hemangiomas of the head, neck and chest with associated vascular brain anomalies: a complex neurocutaneous.

80. Plane, L., Dupoirieux, L. (1996) Indications raisonnées de 1 embolisation dans les malformations vasculaires de la face. Rev. Stomatol. Chir. maxillofac., 97, 5, 295-300.

81. Plessner, H., Rasmussen, J. (1983) Capillary haemangiomas of the eyelid and orbit. A review of 5 children. Acta Ophtal. (Kbh.), 61, 4, 645-654.

82. Průcha, M. (1982) Léčení hemangiomů orofaciální oblasti kryoterapií a naše zkušenosti s touto léčbou. Čs. stomat., 82, 33-34.

83. Rusciani, L., Rossi, G. (1993) Use of Cryotherapy in the Treatment of Keloids. J. Dermatol. Surg. Onco., 19, 529-534.

84. Sato, M., Shirasuma, K. (1979) Giant cavernous hemangioma of the masseter muscle. J. Oral. Surg., 37, 8, 496-499.

85. Sebag-Montefiore, D. D., Biggs, D., Dean, E. (1994) Inoperable pediatic cerebral angiomas successfully treated by stereotactic radiotherapy. Proc. Am. Soc. Clin. Oncol., 13, 1445.

86. Shafrov, V. V., Poliaev, I. A., Konstantinov, K. V., Mazokhin V. N., Kulakov, O. B. (1994) Use of ultra high-frequency electromagnetic fields in pediatric surgery. Vestn. Ross. Akad. Med. Nauk. (Russia), 3, 23-25.

87. Sidky, Y. A., Borden E. C. (1987) Inhibition by interferons: effects on tumor - and lymfocyte - induced vascular responses. Cancer Res., 47, 5155-5161.

88. Spiller, J., Sharma, V., Woods, G. (1992) Difusse neonatal haemangiomatosis treated successfully with interferon alfa $2 \mathrm{a}$. J Amer. Acad. Dermatol., 27, 102-104.

89. Szyskowska, A. M. (1986) Das histologische Bild der elastischen und kollagenen kryochirurgischen Eingriffen and der Schlemhaut der Kaninchenzunge. Genbaurs. Morph. Jahrb. Laepzig, 132, 6, 847-859.

90. Šebestová, V. (1987) Kryalizace. Vztah experimentu a kliniky. Kandidátská disertační práce, Brno.

91. Šulcová, V., Hrecký, D. (1993) Kryoterapie u retinopatie nedonošených. Sb. Věd. Pr. Lék. Fak. KU v Hradci Králové, 36, 56-64.

92. Tazi, Z., Lasjunnias, P., Dyond, D. (1982) Malformations vasculaires invasives de la face et du scalp. Evaluation diagnostique et therapeutiguae par le angiographic. Rev. Stomatol. Chir. Maxillofac., 83, 24-35.

93. Teske, S., Ohlrich, S. J., Gole, G. (1994) Treatment of orbital capillary haemangioma with interferon. Australian and New Zealand Journal of Ophtalmology, 22, 1, 13-17.

94. Thwaites, M., Tatum, R. (1988) Hemangiomas: vascular malformations of childhood. Report of a case with literature review. Pediatric Dentistry, 19, 11, 841-845.

95. Toman, J., Mazánek, J. (1979) Hemangiomy orofaciální oblasti u dětí a jejich terapie včetně intraarteriální embolizace. Čs. Stomat., 79, 5, 326-331.

96. Toman, J., Mazánek J. (1982) Nádory úst a obličeje. Avicenum, Praha.

97. Tonner, P. H., Scholz, J. (1994) Possible lung embolism following embolization of hemangioma with fibrin glue. Anaesthesist (Germany), 43, 9, 614-617.

98. Váchová, A., Rieblová, V. (1978) Některé nové aspekty péče o děti s hemangiomy. Čs. Pediat., 33, 9, 527-530.

99. Voigt, K. (1978) Angiographic, operative and histologic findings after embolization of craniofacial angiomas. Neurocardiology, 16, 424-427.

100. Walsh, J. T., Flatte, T. J., Deutsch, T. F. (1989) Er.: YAG Laser Ablation of Tissue Type on Thermal Damage. Lasers in Surgery and Medicine, 9, 314-326.

101. White, C. W. (1990) Treatment of haemangiomatosis with recombinant Interferon alfa. Seminar. Haematol., 27, 15-22.

102. White, C. W., Sondheimer, H. M., Crouch, E. C. (1989) Treatment of pulmonary hemangiomatosis with recombinant Interferon alfa 2a. N. Engl. J. Med., 320, 1197-2000.

103. White, C. W., Wolf, J. (1991) Treatment of childhood angiomatous diseases with recombinant interferon alfa-2a. J. Pediatr., 118, 59-66. 
104. White, C. W., Iyer, R. V., Zu, A. (1998) Alpha Interferon for treatment of aggressive vascular neoplasms in infants, children and young adults. California, USA. Poster.
105. Williams, M. D., Pearson, M. H., Thomas, F. D. (1992) Arterial embolization of a facial haemangioma. Br. Dent. J., 173, 102-104. 